\title{
Benthic macroinvertebrates in the Paranapanema reservoir cascade (southeast Brazil)
}

\author{
Jorcin, A. * and Nogueira, $M G$. \\ Departamento de Zoologia, Instituto de Biociências, Campus de Rubião Júnior, \\ Universidade Estadual Paulista - UNESP, \\ CEP 18618-000, Botucatu, SP, Brazil \\ *e-mail: ajorcin@ibb.unesp.br
}

Received January 3, 2008 - Accepted January 3, 2008 - Distributed November 30, 2008

(With 3 figures)

\begin{abstract}
In this study, the composition, specific richness and abundance of benthic macroinvertebrates $(<250 \mu \mathrm{m})$ from sediments of eight reservoirs of the Paranapanema River (southeast Brazil), as well as from the main tributaries (Taquari, Pardo and Tibagi) and the mouth zone into the Paraná River were analyzed. Nineteen points distributed along $700 \mathrm{~km}$ were sampled quarterly (8 campaigns) during a two-year period (2000 and 2001). The zoobenthos was characterized by a high species richness, (c.a. 100 taxa), with the predominance of Diptera Chironomidae (c.a. 50 taxa). There was a great spatial variation in the assemblage structure, mainly when compared the lacustrine zones of the reservoirs in relation to the fluvial stretches. The Oligochaeta Narapa bonettoi was dominant in sampling stations with sandy sediments and high water velocity, mainly in the Pardo River and in the upstream and downstream of the Paranapanema river mouth (Paraná River). Branchiura sowerbyi, other numerically important Oligochaeta, was abundant in regions of the upper and middle Paranapanema basin. The mollusk bivalve Corbicula fluminea was widely distributed, occurring in most stations and sampling periods. A certain increment in richness and abundance of taxa occurred in the middle Paranapanema. Lower depth, higher flow and increase in the trophic conditions seem to favor the benthic fauna development in this region. A seasonal variation pattern during the two years of study could not be detected, especially concerning the zoobenthos abundance.
\end{abstract}

Keywords: zoobenthos, spatial distribution, temporal distribution, tropical river.

\section{Macroinvertebrados bentônicos dos reservatórios em cascata do rio Paranapanema (sudeste, Brasil)}

\begin{abstract}
Resumo
Neste estudo, foi analisada a composição, riqueza específica e abundância de macroinvertebrados bentônicos de oito reservatórios do rio Paranapanema, assim como nos principais tributários (Taquari, Pardo e Tibagi) e zona de desembocadura no rio Paraná. Dezenove pontos distribuídos ao longo de $700 \mathrm{~km}$ foram amostrados trimestralmente (oito campanhas) durante dois anos consecutivos (2000 e 2001). O zoobentos foi caracterizado por uma alta riqueza de espécies (c.a. 100 taxa), com a predominância de Diptera Chironomidae (c.a. 50 taxa). Foi observada uma grande variação espacial na estrutura das assembléias, principalmente quando comparadas às zonas lacustres dos reservatórios e aos trechos fluviais. O Oligochaeta Narapa bonettoi foi dominante em estações de amostragem com sedimento arenoso e elevada velocidade de correnteza, principalmente no rio Pardo e na montante e jusante da zona de desembocadura do rio Paranapanema no rio Paraná. Branchiura sowerbyi, outro Oligochaeta numericamente importante, foi abundante no trecho superior da bacia. O molusco bivalve Corbicula fluminea mostrou-se amplamente distribuído, ocorrendo na maioria dos locais e períodos amostrados. Uma elevação da riqueza e abundância ocorreu no médio Paranapanema. Menor profundidade, maior fluxo e aumento da trofia parecem favorecer o desenvolvimento da fauna bentônica nesta região. Um padrão de variação sazonal durante os dois anos de estudo não pôde ser detectado, principalmente relacionado à abundância de organismos.
\end{abstract}

Palavras-chave: zoobentos, distribuição espacial, distribuição temporal, rio Paranapanema. 


\section{Introduction}

The anthropogenic influence in the drainage basins, including river damming and removal of riparian vegetation, changes the natural flow of matter and energy along rivers. Modifications in the nutrient cycles, especially of nitrogen and phosphorus, and in the availability of organic subtracts, for instance, are expected and should affect directly or indirectly the benthic communities. Gumiero and Salmoiraghi (1998) showed that both abundance and biomass of benthic communities varied significantly when comparing regulated environments (dammed up) to those not regulated, including responses to seasonality (pluviometric regime). The authors concluded that dams promote a discontinuity, inducing considerable changes in the community organization along the longitudinal gradient. Barros and Trivinho-Strixino (2002), studying Chironomidae distribution, observed a loss of diversity downstream from the dam and a discreet downstream recovery when the river returns to its normal course.

The taxonomic richness and numerical abundance of the populations, the parameters usually analyzed in the studies of benthic communities, are useful tools for a rapid and precise detection of ecosystem alterations. This is due to the differential sensibility of the organisms to distinct pollutants and contaminant substances (Wright et al., 1994). In an analysis of the Chironomidae distribution in reservoirs with different levels of trophy, Higuti et al. (2005) observed a higher taxonomical richness in the oligotrophic ones and also that specific genera dominate in eutrophic environments.

Despite the widespread series of reservoirs in Brazil, there is little information on their effects on zoobenthos community organization. For the cascade of reservoirs of the Iguaçu River (south Brazil), Takeda et al. (2005a) observed an increasing tendency in the diversity index from the upstream to downstream direction.

Additionally to the longitudinal river gradients, the inherent internal spatial complexity of large tropical reservoirs (e.g. Henry et al., 1998 and Nogueira et al., 1999 for the Paranapanema system) also influences the benthic community. For the Rosana Reservoir (SP-PR, Brazil), Resende et al. (2003) found the highest diversity in the lacustrine area when compared to the central and fluvial zones. Laterally, the connection to floodplain wetlands, such as marginal lakes is also of major importance for the macroinvertebrate diversity in reservoir ecosystems (Kudo et al., 2006).

The aim of the present work was to study the composition, distribution, and abundance of benthic fauna along a cascade of reservoirs built up in the Paranapanema River, southeast Brazil, in different seasonal periods.

\section{Material and Methods}

The Paranapanema River is one of the tributaries of the high Paraná River (La Plata Basin) located between latitudes $22^{\circ}-26^{\circ} \mathrm{S}$ and longitudes $47^{\circ}-54^{\circ} \mathrm{W}$. Part of the frontier between the states of Paraná and São Paulo
(Figure 1) is determined by the Paranapanema. The main river course, in an east-west direction, has a total extension of $929 \mathrm{~km}$ between the altitudes (a.s.1.) 809 and $239 \mathrm{~m}$. The basin area is of approximately $100,800 \mathrm{~km}^{2}$.

Eleven hydroelectric power plants have been constructed in the main course of the Paranapanema River, since the mid twentieth century. In this study, 8 reservoirs were considered: Jurumirim is the first, followed by Chavantes, Salto Grande, Canoas I, Canoas II, Capivara, Taquaruçu and Rosana. The influence of the seasonality in the region is mainly defined by the pluviometric regime - rainy (summer) and dry (winter) seasons. A general and limnological description of this cascade reservoir system is found in Nogueira et al. (2006).

The sediment samples were collected in 19 sampling points distributed along the Paranapanema River course. Eight reservoirs were sampled, as well as the three main tributaries - Taquari, Pardo and Tibagi and the upstream and downstream zones of the Paranapanema River mouth into the Paraná River. Except for the Canoas complex, the reservoirs were sampled in the lacustrine (dam) and riverine (river-reservoir) (upstream) zones (Figure 1). Samplings were carried out quarterly (January-summer; April-fall; July-winter; October-spring) in 2000 and 2001.

Four sediment samples were collected at each sampling point, with a Van Veen type dredger, (opening of $0.038 \mathrm{~m}^{2}$ ). Three samples were used for analysis of the benthic fauna and one for sediment characterization. This last sample was immediately frozen for posterior textural classification and determination of average grain size (Wentworth scale), percentage of different sedimentologycal fraction and percentage of organic matter (OM) (Håkanson and Jansson, 1983) and total nitrogen (TN) (Kjeldhal - Büchi analyser) and total phosphorus (TP) (Andersen, 1976).

For the benthic fauna analysis, the sediment samples were immediately washed at the collection site using a $250 \mu \mathrm{m}$ mesh size net, in order to remove the excess of material (mainly mineral particles and organic detritus) keeping the macroinvertebrates. Afterwards, the material was transferred to plastic bags and fixed with $8 \%$ formalin.

The samples were rewashed (tap water $250 \mu \mathrm{m}$ mesh size metal sieve) at the laboratory in order to remove the remaining excess material. The separation of the fauna organisms was performed under a binocular stereoscopic microscopy, been conserved in alcohol $70 \%$. Identification followed mainly Wiederholm (1983), Mansur et al. (1987), Brinkhurst and Marchese (1989), Pennak (1989), Epler (1992), Lopretto and Tell (1995), Trivinho- Strixino and Strixino (1995) and Merrit and Cummings (1996). The samples are deposited in the Freshwater invertebrate collection of the Department of Zoology, Bioscience Institute, State University of São Paulo (UNESP) - Botucatu Campus.

The abundance of the benthic fauna was calculated (ind. $\mathrm{m}^{-2}$ ) as well as the taxonomical richness. In order 


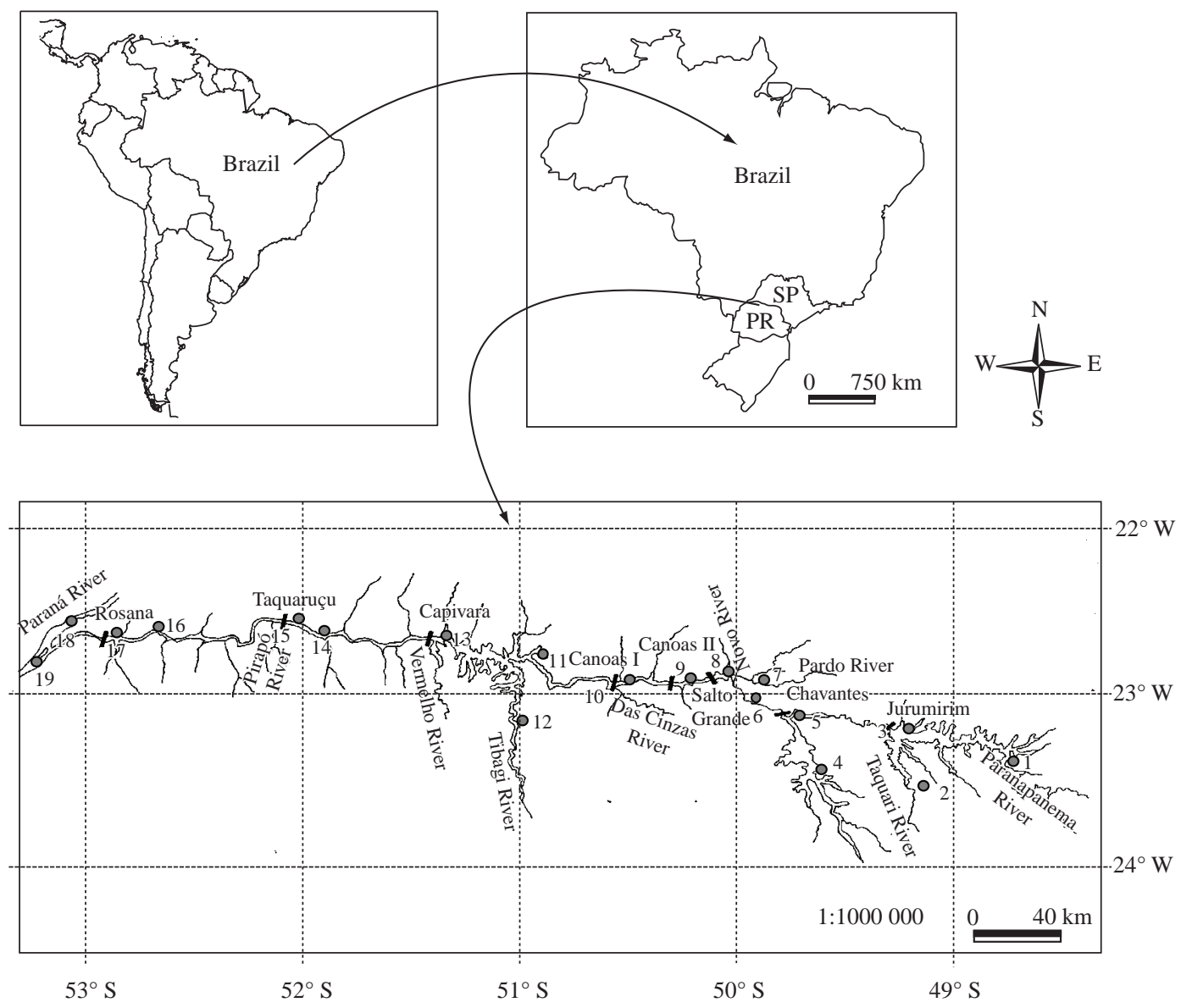

Figure 1. Geographical position of the Paranapanema River and location of the sampling stations.

to determine significant statistical differences of the biological data among sampling periods and sampling points, the F test was applied (Elliott, 1977). Correlation analysis ( $r$ - Pearson, rectangular matrix) was performed between values of the sediment variables and the main zoological groups abundance.

\section{Results}

\subsection{Sediments}

The results of the analyses of the sediment characterization are shown in Table 1 (minimum and maximum values).

Three sampling stations had a textural classification of medium sand type and also a low concentration of organic matter: Pardo River, upstream and downstream of the Paranapanema mouth (Paraná River). Therefore, the sediments of these stations can be classified as mineral (Ungemach, 1960 apud Esteves, 1998). The stations Jurumirim dam, Salto Grande dam and upstream, Canoas I and Taquaruçu upstream and dam, had a fine sand type textural classification, with low organic matter content, being considered as mineral sediment too. The remaining stations exhibited higher silt and organic matter content, as well as larger particle diameter in phi scale, being classified as silty and organic sediments.

Minor variation of the organic matter percentage was recorded, generally not affecting the sediment classification. Minimum values of organic matter were recorded at the stations Pardo River, upstream and downstream zones of the Paranapanema mouth, which oscillated between 0.2 and $1 \%$. The maximum concentrations of organic matter were recorded at Chavantes upstream, with 22.6\% in January 2000 and 23.2\% in April of the same year. The Taquari River also presented a high proportion of organic content in the sediments reaching the value of $21.8 \%$ in April 2000.

Nitrogen concentration in the sediments oscillated largely both among periods and among sampling stations. Minimum concentrations, similar to those observed for organic matter, were found at the stations Pardo River, in the upstream and downstream zones of the Paranapanema River, from undetected values to 
Table 1. Minimum and maximum values of the variables measured in the sediment of the sampling stations of the Paranapanema River basin.

\begin{tabular}{|c|c|c|c|c|c|c|}
\hline Stations & $\begin{array}{c}\text { Mean } \\
\text { diameter }(\emptyset)\end{array}$ & $\begin{array}{c}\text { Sand } \\
\text { Percentage }\end{array}$ & $\begin{array}{c}\text { Organic matter } \\
\text { percentage }\end{array}$ & $\begin{array}{c}\text { Total nitrogen } \\
\text { (mg. }{ }^{-1} \text { d.w.) }\end{array}$ & $\begin{array}{c}\text { Total } \\
\text { phosphorous } \\
\left(\text { (mg g }^{-1} \text { d.w. }\right)\end{array}$ & $\begin{array}{c}\text { Textural } \\
\text { classification }\end{array}$ \\
\hline M J & 4.3-4.5 & $0.5-22.2$ & $8.0-11.5$ & $1.66-6.55$ & $0.43-0.95$ & $S$ \\
\hline RT & $3.9-4.5$ & $1.3-26.7$ & $3.7-21.8$ & $2.48-7.94$ & $0.35-1.35$ & S \\
\hline BJ & $3.4-4.1$ & $35.7-69.0$ & $5.3-22.6$ & $0.70-5.99$ & $0.11-0.59$ & F. S. \\
\hline $\mathrm{MCh}$ & $3.3-4.6$ & $0.3-1.1$ & $3.1-23.2$ & $1.60-7.58$ & $0.63-1.23$ & S \\
\hline $\mathrm{BCh}$ & $3.9-4.5$ & $0.6-22.3$ & $11.6-19.8$ & $3.17-10.89$ & $0.45-1.42$ & $\mathrm{~S}$ \\
\hline MSG & $3.8-4.3$ & $23.4-71.1$ & $2.8-8.1$ & $1.83-4.30$ & $0.25-1.06$ & F.S. \\
\hline $\mathrm{RP}$ & $1.6-2.4$ & $98.1-99.9$ & $0.2-1.0$ & $0-2.69$ & 0-0.02 & M.S. \\
\hline BSG & $2.7-4.5$ & $12.9-84.9$ & $2.4-20.2$ & $1.99-9.07$ & $0.68-1.37$ & F.S. \\
\hline CII & $4.0-4.5$ & $1.7-42.7$ & $8.8-20.4$ & $2.20-7.18$ & $0.71-1.60$ & S \\
\hline CI & $3.3-4.5$ & $2.8-72.8$ & $1.2-15.8$ & $0.21-8.0$ & $0.53-1.53$ & F.S. \\
\hline MC & 4.4-4.5 & $0-1.1$ & $11.3-21.2$ & $2.05-10.01$ & $0.88-1.46$ & S \\
\hline RTi & $4.4-4.5$ & $0-0.5$ & $13.2-16.4$ & $2.66-8.61$ & $0.03-1.96$ & S \\
\hline $\mathrm{BC}$ & $4.3-4.5$ & $0.5-18.1$ & 8.4-20.1 & $1.80-8.54$ & $0.31-1.21$ & $\mathrm{~S}$ \\
\hline MT & $3.4-4.2$ & $25.4-92.2$ & $1.9-11.0$ & $0-3.50$ & $0.15-0.99$ & F.S. \\
\hline BT & $3.6-4.4$ & $11.1-59.5$ & $1.8-12.4$ & $2.0-4.17$ & $0.25-1.15$ & F.S. \\
\hline MR & $4.1-4.5$ & $5.1-24.3$ & $8.2-15.0$ & $3.07-7.40$ & $0.36-1.50$ & S \\
\hline $\mathrm{BR}$ & $3.7-4.5$ & $0.7-46.9$ & $1.0-17.3$ & $0-7.49$ & 0-1.61 & S \\
\hline MFP & $1.1-2.2$ & 98.6-100 & $0.2-0.4$ & $0-0.16$ & $0-0.05$ & M.S. \\
\hline JFP & $1.2-2.2$ & 83.4-98.4 & $0.2-0.7$ & $0-0.30$ & $0-0.02$ & M.S. \\
\hline
\end{tabular}

S: silt/clay; F.S.: fine sand; M.S.: medium sand

$0.3 \mathrm{mg} \cdot \mathrm{g}^{-1}$ of dry weight (d.w.). The maximum values were recorded at Chavantes dam in the months of July and October of 2000 with 10.89 and $10.87 \mathrm{mg} \cdot \mathrm{g}^{-1}$ d.w., respectively; at Capivara upstream with $10.1 \mathrm{mg} \cdot \mathrm{g}^{-1}$ d.w. in July 2000 and at Salto Grande dam with $9.07 \mathrm{mg} \cdot \mathrm{g}^{-1}$ d.w. in October 2000.

A similar pattern was observed for the variation of total phosphorus. Nevertheless a certain increase in this nutrient concentration was recorded in some sampling periods of 2001. In Tibagi River, for example, a small increase in PT concentration was recorded, varying from $1.52 \mathrm{mg} . \mathrm{g}^{-1}$ d.w. in January 2001 to $1.96 \mathrm{mg} \cdot \mathrm{g}^{-1}$ d.w. in October of the same year. This tendency was also observed for Capivara dam and Taquaruçu upstream. Undetectable phosphorus concentrations were eventually registered at Pardo River, Rosana dam, upstream and downstream of the Paranapanema mouth.

A detailed description and interpretation of nutrients (T-N and T-P) and metals and pesticides concentrations in the Paranapanema basin sediments is provided by Jorcin and Nogueira (2005a; b) and Nogueira and Jorcin (2006), respectively.

\subsection{Zoobenthos}

\subsubsection{Composition and distribution}

A total of 96 taxa were found along the Paranapanema River and affluents during the studied periods (Table 2). However, its is important to note that several organisms were not identified at species level, due to intrinsic problems of the taxonomical studies of this community of organisms and precluding that an even higher richness could be determined. The benthic macroinvertebrates were represented by 7 major zoological groups: Mollusca, Crustacea, Acari, Annelida, Nematoda, Nematomorpha, and Insecta. The greatest richness was observed in the class Insecta, with 60 taxa, followed by Annelida with 15, Crustacea (Ostracoda) with 10 and Mollusca with 8. Acari, Nematoda and Nematomorpha were taxonomically poorer, with only one taxa of each group.

Among the Mollusca, higher richness corresponded to the class Gastropoda (6), although the Bivalvia had a higher relative abundance, specifically due to the presence of Corbicula fluminea. Among the Annelida, the Oligochaeta was the most specious class, with 13 different taxa, while the Hirudinea contributed with only 
2 taxa. The Insecta was the most diversified class, with six different orders. The order Diptera was the best represented one, with 50 different taxa.

The number of taxa found at the sampling stations, grouped in the main zoological groups - Mollusca, Annelida, Insecta (Diptera) and others, is shown in Figure 2. The higher richness of Diptera over the other groups is clearly observed, as well as the high number of taxa found in the Pardo River (44), followed by Salto Grande upstream (30), Canoas II (29) and Taquaruçu upstream (23).

In general, a certain increase in richness was observed in the middle/middle low Paranapanema region, among Salto Grande upstream stations up to the Taquaruçu dam, after a marked decline in the large and deep reservoirs of Jurumirim and Chavantes. Significant differences were not observed among the sampling periods ( $F$ test analysis), in terms of richness values.

Insecta and Annelida are the predominant groups in the benthic fauna of the Paranapanema river and tributaries. Considering all the sampling periods, the proportion of Insecta in the tributaries was slightly superior $(65.8 \%)$ to the one found in the reservoirs $(58.1 \%)$. For Annelida and Mollusca, the proportion was superior in the reservoirs $(20.7$ and $10.1 \%$, respectively, in relation to the tributaries, 16.7 and $7 \%$, respectively). Among the Insecta, Diptera was the main order, regarding richness, abundance and spatial and temporal distribution.

In the Paranapanema basin main axis (river and reservoirs) the oligochaeta Branchiura sowerbyi was the best representative of the class Annelida, in terms of distribution and abundance, occurring mainly in the high and middle Paranapanema regions. For the tributaries, a high occurrence of the tubificidae $B$. sowerbyi and Paranadrilus descolei was also observed. At Pardo River station and in the upstream and downstream zones of the Paranapanema mouth, the narapidae Narapa bonettoi predominated. A higher number of Annelida species was detected in the high and middle region of the Paranapanema basin - at the stations Jurumirim upstream (6) and Taquari River (6), Salto Grande upstream (9), Pardo River (6) and Canoas II (4).

Among the Mollusca, the bivalve Corbicula fluminea was largely distributed in the main river and tributaries, occurring in 15 sampling stations.

The Crustacea was also widely distributed and their presence was detected in 14 sampling stations, with the 10 different species, which were restricted to the class Ostracoda.

The Nematoda occurred in 10 sampling stations. All representatives of this group belonged to the same order, Dorylaimida.

The groups poorly represented were Acari, found only at three sampling stations (Jurumirim upstream, Pardo River and Rosana dam), and Nematomorpha with only one individual found at the Salto Grande upstream station.

The Insecta, as mentioned before, was the best represented group in the benthic fauna, being found at practically all the sampled stations. The order Diptera, especially Chironomidae, was largely dominant, followed by the Trichoptera, Odonata, Ephemeroptera, Collembola and Coleoptera.

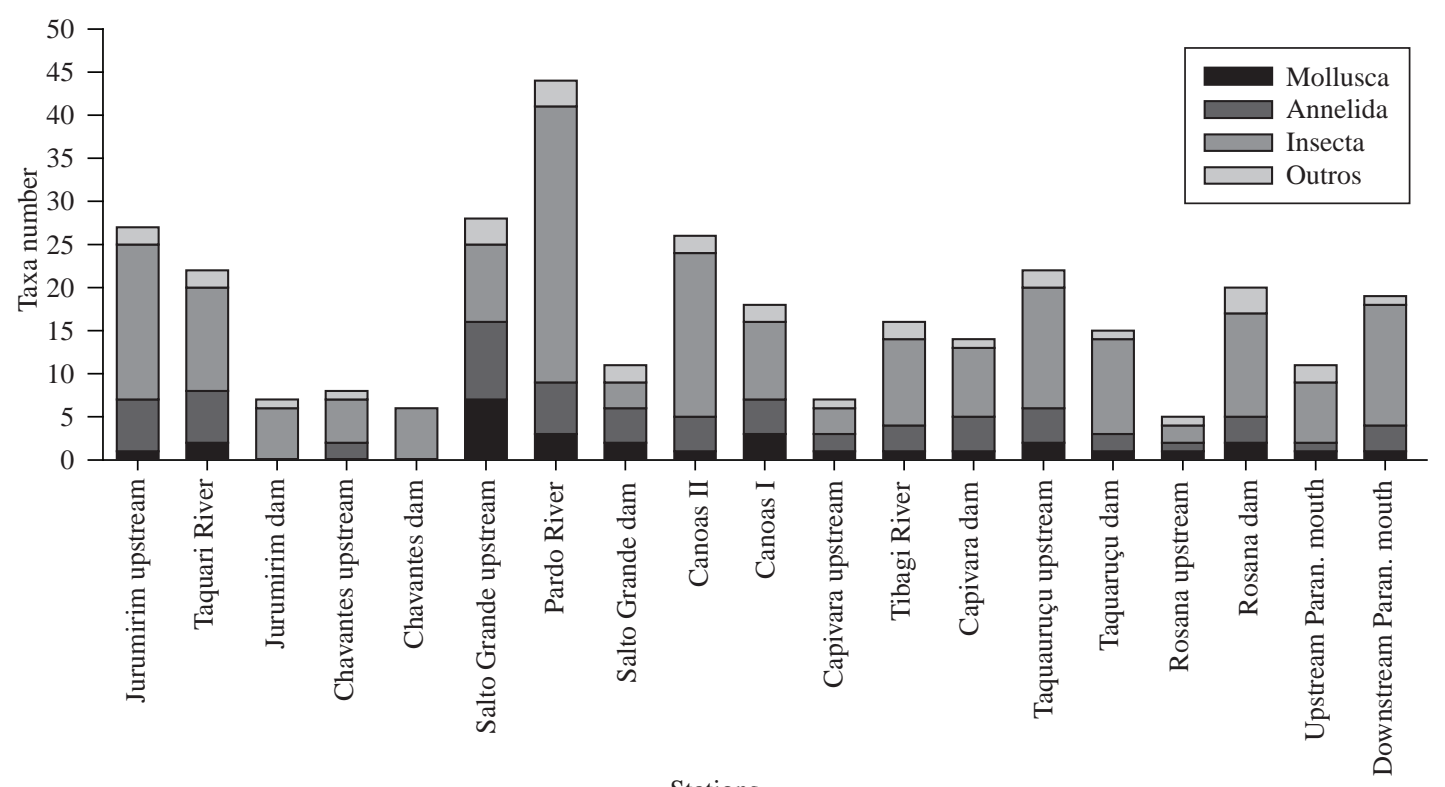

Stations

Figure 2. Total number of benthic macroinvertebrate taxa (grouped in Mollusca, Annelida, Insecta and others) at the different sampling stations in the Paranapanema River Basin. 
Table 2. List of benthic macroinvertebrate taxa identified in the Paranapanema River basin.

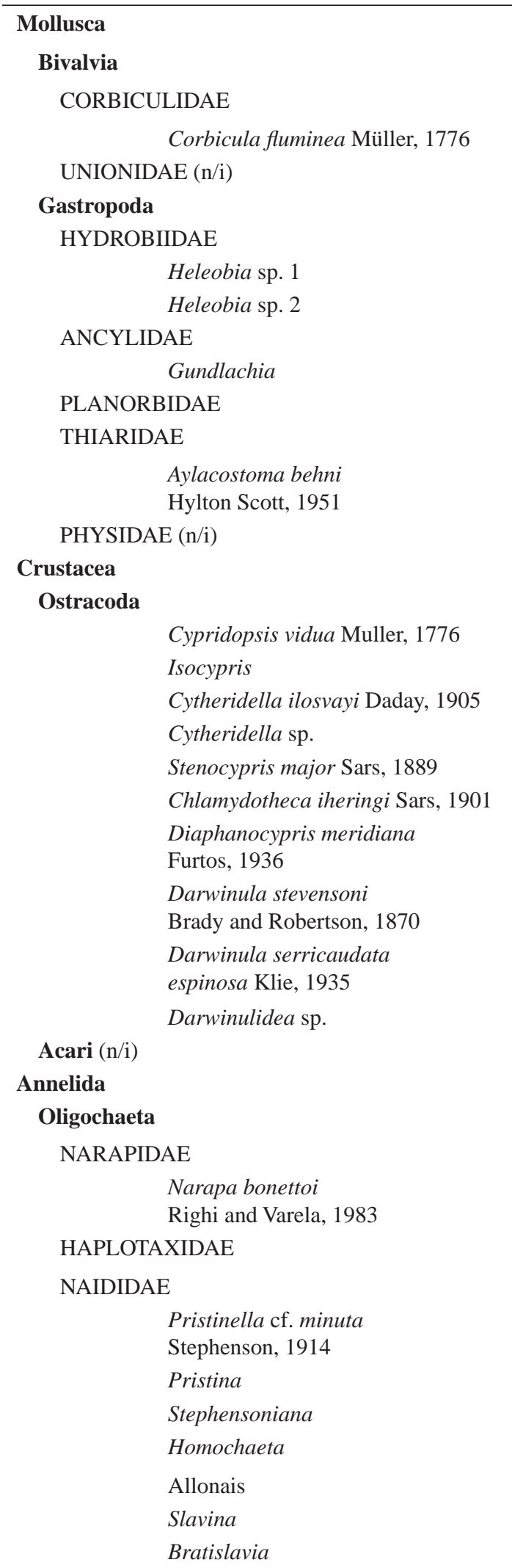

TUBIFICIDAE

Paranadrilus descolei Gavrilov, 1955

Aulodrilus limnobius Bretscher, 1899

Branchiura sowerbyi Beddard, 1892

Limnodrilus cf.

Hirudinea

GLOSSIPHONIDAE

Batracobdella

Nematoda

Dorylaimida $(\mathrm{n} / \mathrm{i})$

Nematomorpha $(\mathrm{n} / \mathrm{i})$

Insecta

Trichoptera

LEPTOCERIDAE

Setodes

Nectopsyche

POLYCENTROPODIDAE

Neureclipsis

Odonata

GOMPHIDAE

Aphylla

Progomphus

\section{Collembola}

ISOTOMIDAE

ENTOMOBRYIDAE

Entomobrya

\section{Ephemeroptera}

POLYMITARCYIDAE

Campsurus

TRICORYTHIDAE

Leptohyphes

Coleoptera

ELMIDAE (n/i)

\section{Diptera}

CHAOBORIDAE

Chaoborus

STRATIOMYIDAE

Stratiomys

CERATOPOGONIDAE

CHIRONOMIDAE

Ablabesmyia (Karelia)

Ablabesmyia gr. annulata Say, 1823

Alotanypus

Brundiniella

Chironomus gr. salinarius

Kieffer, 1915

Chironomus gr. decorus

Cladopelma 
Table 2. Continued...

\begin{tabular}{l} 
Cladotanytarsus \\
Clynotanypus \\
Coelotanypus \\
Cricotopus sp. 1 \\
Cricotopus sp. 2 \\
Cryptochironomus sp. 1 \\
Cryptochironomus sp. 2 \\
Dicrotendipes sp. \\
Dicrotendipes sp. 3 \\
Djalmabatista pulcher \\
Johansen, 1908 \\
Djalmabatista sp. 2 \\
Gênero A sp. 2 \\
Gênero A sp. 4 \\
Gênero B \\
Goeldichironomus xiborena \\
Fittkau, 1965 \\
Harnischia cf. \\
Larsia \\
Lopescladius \\
Microchironomus cf. \\
Microtendipes \\
\hline
\end{tabular}

$\mathrm{n} / \mathrm{i}=$ not identified

Despite having a wide distribution along the river, a slight increase in specific richness of Chironomidae was observed in the region of the middle Paranapanema.

The genus Chaoborus was relatively well represented, being found at 8 sampling stations. Among the Chironomidae, Coelotanypus occurred in 16 stations, followed by the B genus, represented in 10 stations. Djalmabatista sp. occurred in 7 stations, and Polypedilum, represented by $P$. tripodura, P. asheum, $P$. sp. 1 and $P$. sp. 2 was found at 6 stations. The remaining zoobenthic taxa had a more restricted spatial and temporal distribution.

\subsubsection{Abundance}

A high temporal variability in the total abundance of organisms (ind. $\mathrm{m}^{-2}$ ) was observed for most sampling stations in the Paranapanema River/reservoirs and tributary rivers (Figure 3). A seasonal variation pattern could not be detected, considering the two years of study.

The stations Pardo River, upstream and downstream zones of the Paranapanema mouth exhibited a relatively high density of organisms in 2001, as a consequence of a remarkable increase in density of Narapa bonettoi.

In the high Paranapanema region, the sampling points located in the upstream zones of the reservoirs exhibited values around 3,000 ind. $\mathrm{m}^{-2}$, higher than the ones observed near the dams. Corbicula fluminea and
Nilothauma sp. 1
Orthocladiinae (n/i)
Parachironomus sp. 1
Parachironomus sp. 3
Paracladopelma
Parakiefferiella
Paralauterborniella
Polypedilum (Asheum)
Polypedilum (Polypedilum) sp. 1
Polypedilum (Polypedilum) sp. 2
Polypedilum (Tripodura)
Procladius sp. 1
Procladius sp. 2
Pseudochironomus
Robackia
Saetheria (cf.)
Stenochironomus
Tanytarsini gênero B
Tanytarsus
Zavreliella (cf.)
Zavrelimyia

Paranadrilus descole $i$ were the two species that occurred in higher densities in this region of the basin. Among the Insecta, species of Chironomidae and the Ephemeroptera Campsurus were the organisms with higher abundance, mainly at the Taquari River station.

In general the sampling stations in the middle Paranapanema basin exhibited a higher organism abundance, mainly in the tributaries and upstream zones of the reservoirs. In most samplings $C$. fluminea and B. sowerbyi were more abundant than the other taxa. At the Pardo River station, high densities of organisms were observed during the whole study. A remarkable occurrence of $N$. bonettoi at this point was observed, especially in July and October, with maximum values of 31,591 ind. $\mathrm{m}^{-2}$ in July 2001 and 123,474 ind. $\mathrm{m}^{-2}$ in October 2001. A high density of C. Aluminea also occurred at this station, reaching 7,641 ind. $\mathrm{m}^{-2}$ in April 2000. Another important species in this region was the Ostracoda Diaphanocypris meridiana, especially in the upstream of Salto Grande Reservoir, with 800 ind.m ${ }^{-2}$, approximately.

In the low Paranapanema region, a certain decrease in organism density occurred, however expressive fluctuations in the values were also observed. C. fluminea and $B$. sowerbyi continued to occur as important taxa in different sampling points of this region. A high organism 
density $\left(6,244\right.$ ind $\left.\mathrm{m}^{-2}\right)$ was found in the Tibagi River in January 2000, basically due to the contribution of Unionidae bivalves ( $99.3 \%$ of the total zoobenthos). In the rest of the months, the maximum density for this sampling station did not exceed 335 ind. $\mathrm{m}^{-2}$ (April 2001).

At the stations located upstream and downstream to the Paranapanema mouth, into the Paraná River, the zoobenthos abundance was particularly high due to the occurrence of $N$. bonettoi. This species reached a maximum density of 36,353 ind. $\mathrm{m}^{-2}$ at the upstream station (October 2001) and 31,602 ind. $\mathrm{m}^{-2}$ at the downstream station (April 2001). The densities of others taxa were low when compared to the Oligochaeta formerly mentioned.
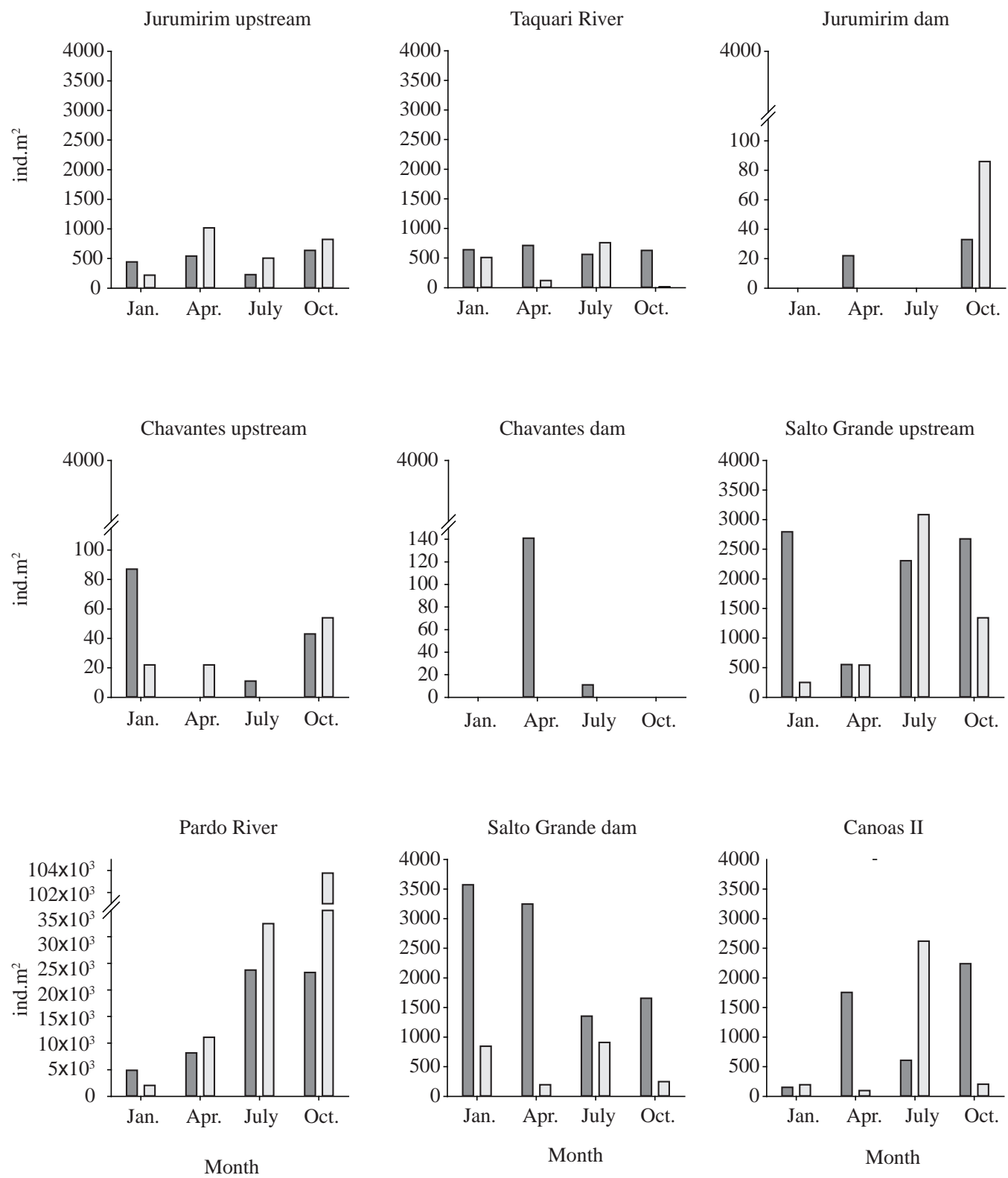

Figure 3. Variation of the benthic macroinvertebrate abundance (ind. $\mathrm{m}^{-2}$ ) at the different sampling stations and periods in the Paranapanema River Basin. 
Canoas I

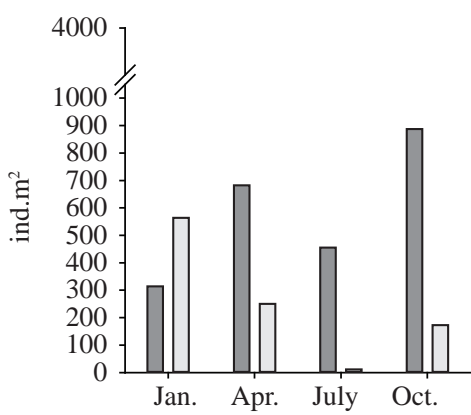

Capivara dam

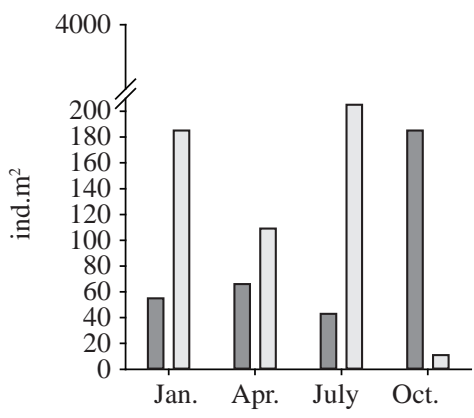

Rosana upstream

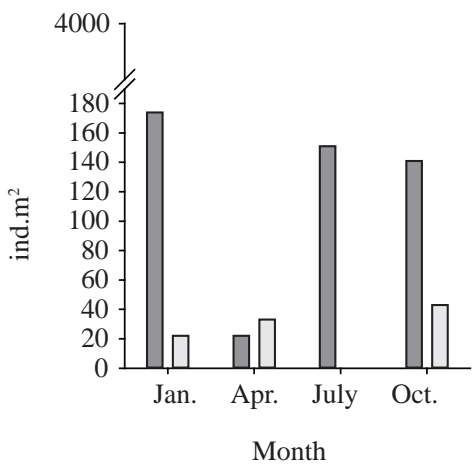

Capivara upstream

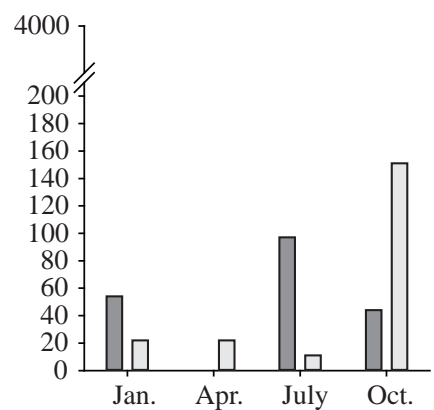

Taquaruçu upstream

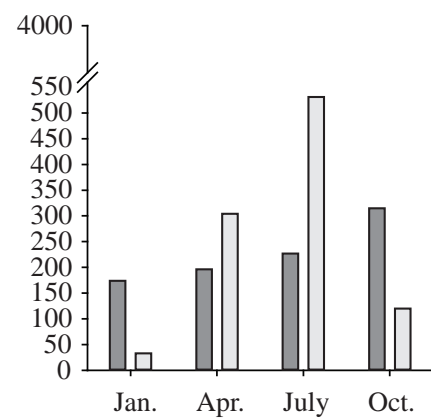

Rosana dam

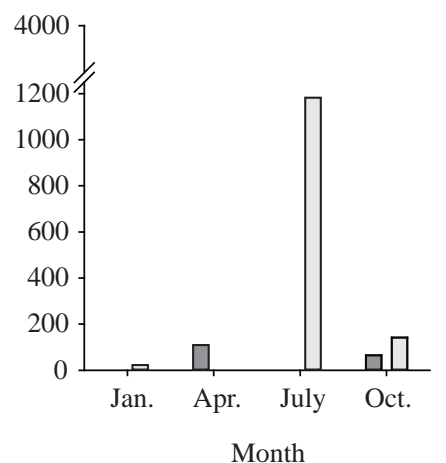

Tibagi River

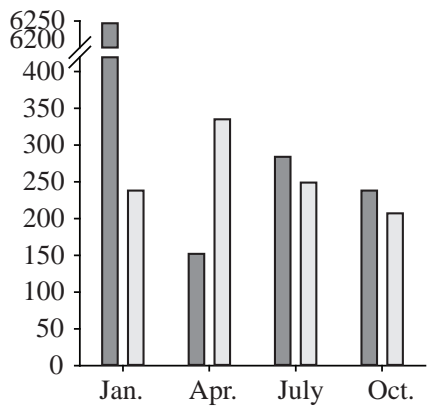

Taquaruçu dam

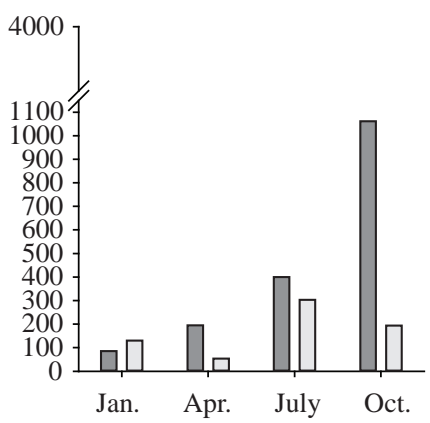

Upstream Paran. mouth

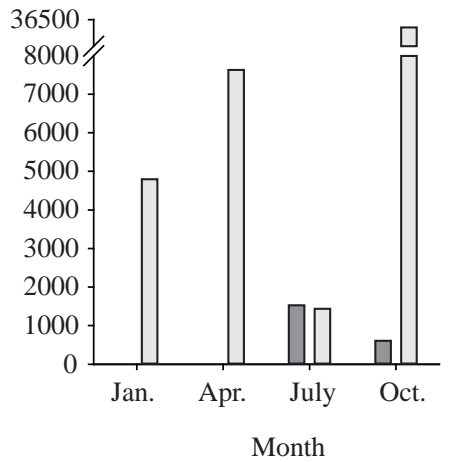

Downstream Paran. mouth

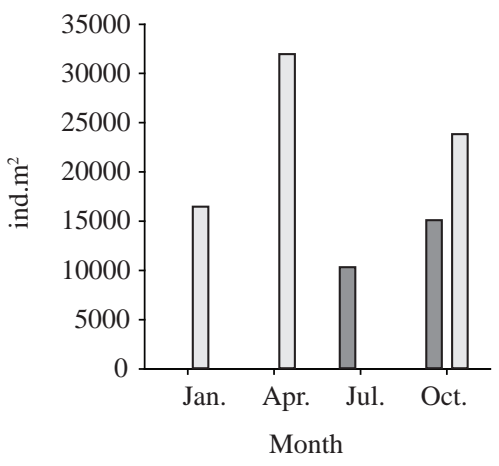

2000

Figure 3. Variation of the benthic macroinvertebrate abundance (ind. $\mathrm{m}^{-2}$ ) at the different sampling stations and periods in the Paranapanema River Basin. 
For the Oligochaeta, the results evidenced a significant correlation $(\alpha<0.05)$ with several variables: NT $(\mathrm{r}=-0.70)$, PT $(\mathrm{r}=-0.63)$, OM $(\mathrm{r}=-0.68)$, phi $(\mathrm{r}=$ $-0.75)$, depth $(\mathrm{r}=0.54)$. The remaining benthic groups did not have significant correlation with the analyzed variables.

\section{Discussion}

The benthic macroinvertebrates of the Paranapanema basin was characterized by a high species richness, c.a. 100 taxa, with a great predominance of Diptera Chironomidae, c.a. 50 species. These results are similar to the ones obtained by Jorcin et al. (in press) for the large reservoir of Porto Primavera (123 taxa, being 63 Chironomidae) also located in the high Paraná River basin.

The zoobenthos exhibited a large variation in the species composition, abundance and richness distribution along the reservoir cascade system of the Paranapanema River. Important differences, mainly in the species composition and dominance (numerical), were observed between the main river/reservoirs and the tributaries/mouth zone into the Paraná River.

In the Pardo River, as well as in upstream and downstream zones of the Paranapanema river mouth, for example, there are distinctive environmental characteristics: coarse (medium sand) texture and high water velocity (pers. obs.). In these stations, different from the rest of the studied system, there is a high abundance of the Oligochaeta $N$. bonettoi. This is an evidence that the structure of the benthic invertebrate assemblages varies when compared lotic and lacustrine environments of the Paranapanema River basin. Takeda et al. (2001), studying the distribution of this Oligochaeta in the high Paraná River, observed that hydrology is the main factor that affects this organism distribution. According to Marchese (1995), this small-proportioned organism adapts very well to systems with high water velocity, low content of organic matter in sediments and granulometry type from fine to medium sand. All these characteristics are especially evident in the Pardo River and in the upstream and downstream zones of the Paranapanema River mouth, areas where this species reached the maximum densities.

In the case of the reservoir environments, the age of construction of the dam is another important factor for the establishment of different benthic assemblages. Takeda et al. (2005a) also observed that the reservoir age may affect the species diversity, with older reservoirs having a greater diversity of the benthic fauna. In case of the Paranapanema River, Salto Grande was the first reservoir to be built, in 1958. This reservoir, especially in the upstream zone, exhibited a high number of taxa. Its almost 5 decades of existence may have given a chance for the establishment of different species in the new habitats created after the lake filling up. The richness established here might be gradually transferred to the subsequent reservoir (Canoas II and Canoas I).
Nevertheless, a new decrease occurred towards the river mouth, probably influenced by the deeper conditions of the downstream reservoirs.

In terms of intra-reservoir variations the results showed some conspicuous downstream diminution in richness of the bentic fauna. In Jurumirim and Salto Grande the decrease near the dam was of about 20 taxa. In the case of Jurumirim the maximum densities were about 1,000 ind. $\mathrm{m}^{-2}$ in the upstream and only 80 ind. $\mathrm{m}^{-2}$ in the dam zone. Santos and Henry (2001) had already observed this tendency for this reservoir. Jorcin et al. (in press), in a four-year study of the zoobenthos in Porto Primavera Reservoir (SP/MS), also observed higher species richness in the fluvial zone and higher diversity and densities in the transitional (river-reservoir) zones.

In our study, the relative increase in richness and abundance of the benthic macroinvertebrates in the middle Paranapanema basin could also be related to the trophy. Nogueira et al. (2002), based on the water column characteristics, concluded that more eutrophic conditions occur in the reservoirs of the middle basin, when compared with the oligotrophic ones of the high Paranapanema. The authors also detected an improvement of the reservoir water quality located in the river final stretch. Similar tendencies were found by Jorcin and Nogueira (2005a; b) on the basis of sediment characteristics, mainly OM, TP and TN concentrations.

The low depth of the sampling points located in the middle Paranapanema (e.g. upstream and dam stations of Salto Grande, Canoas II and Pardo River), may favor benthic fauna development. The low depth associated to relatively transparent waters - light availability in bottom layers (particularly in the upstream Salto Grande), generate the development of aquatic macrophytes providing more variety of habitats and food resources for the benthic organisms. The Oligochaeta Naididae and Tubificidae are found in a large habitat spectrum. Yet, among the Naididae, Pristina and Allonais have a distribution usually associated to aquatic macrophytes (Alves and Marchese, 2002; Alves et al., 2002). This pattern was also verified in this study, mainly for the sampling stations formerly mentioned.

The occurrence of Chironomidae was important in almost all the sampling points. However, a greater richness of this group was associated to the upstream zones of the reservoirs and to the tributary rivers, such as Pardo and Taquari. The genera Chironomus, Djalmabatista, Coelotanypus and Polypedilum were frequently found, but without presenting a seasonal pattern of variation. This indicates a great tolerance to the different climatic, hydrological and limnological conditions.

Regarding the Mollusca, a clear predominance of C. fluminea was observed. This species occurred in the whole basin and even reaching very high abundance (e.g. 7,641 ind. $\mathrm{m}^{-2}$ in April 2000 at Pardo River station). C. fluminea is an exotic species, from Asia, introduced through the River de La Plata. It was quickly dispersed and displaced many native species (Ituarte, 1981). 
Takeda et al. (2005b), studying 31 reservoirs of distinct hydrographic basins of Paraná State, observed that C. fluminea was predominant in the Paranapanema River reservoirs, mainly in Canoas I and Rosana. According to the authors, the predominance of a sandy riverbed may distinguish the Paranapanema basin from the others they studied.

Bagatini et al. (2003), in order to explain the distribution of $C$. fluminea in Rosana Reservoir, related the biomass accumulation of this organism to the increment of chlorophyll concentration in the water column.

In the present study, as already mentioned, it was observed a wide spatial distribution and, sometimes, in higher densities, of benthic organisms. Temporally, a seasonal pattern of their occurrence has not been determined. As verified by other authors (Takeda, 1999; Takeda et al., 1997; Resende et al., 2003; Jorcin et al., in press), parameters such as nutrient, organic matter concentration and granulometric characteristics of the sediments strongly influence the benthic assemblages structure, mainly for the Oligochaeta and Chironomidae.

Acknowledgements - The authors are grateful to FAPESP for financial support (Process nos. 99/09667-9 and 00/01536-1) and to Duke Energy- Geração Paranapanema for the collaboration of their staff during the fieldwork.

\section{References}

ALVES, RG. and MARCHESE, MR., 2002. Levantamento de espécies de Oligochaeta (Annelida: Clitellata) em alguns habitats aquáticos continentais do Estado de São Paulo (Brasil). In Resumos III Simpósio do programa Biota/Fapesp, 26-28 Novembro, 216 p. São Carlos: UFSCar.

ALVES, RG., ESCARPINATI, SC. and MARCHESE, MR., 2002. Estudo sobre a ecologia de Oligochaeta (Annelida: Clitellata) de ambientes urbanos do Estado de São Paulo (Brasil). In Resumos III Simpósio do programa Biota/Fapesp, 26-28 Novembro, 212 p. São Carlos: UFSCar.

ANDERSEN, JM., 1976. An ignition method for determination of total phosphorus in lake sediments. Wat. Research., vol. 10, p. 329-331.

BAGATINI, YM., HIGUTI, J., TAKAHASHI, MA. and BENEDITO-CECILIO, E., 2003. Variação sazonal e longitudinal da biomassa de Corbicula fluminea (Muller, 1774) no reservatório de Rosana (Paraná/São Paulo). In RODRIGUES, L., AGOSTINHO, AA., GOMES, LC. and THOMAZ, SM. (Eds.). Produtividade em reservatórios e bioindicadores. Maringá, PR: Universidade Estadual de Maringá. p. 161-165

BARROS, TS. and TRIVINHO-STRIXINO, S., 2002. Exúvias de pupas de Chironomidae (Diptera) na caracterização de corpos d'água do Campus e arredores da Universidade Federal de São Carlos. In Resumos III Simpósio do Programa Biota/Fapesp, 26-28 Novembro, 213 p. São Carlos: UFSCar.

BRINKHURST, RO. and MARCHESE, MR., 1989. Guide of the freshwater aquatic Oligochaeta of South and Central America. Coleción Climax (Santa Fe)6, 207p.

ELLIOTT, JM., 1977. Some methods for the statistical analysis of samples of benthic invertebrates. 2 ed. Kendal: Freshwater Biological Association. Scientific Publication, no. 25. 156 p.
EPLER, JH., 1992. Identification manual of the larval Chironomidae (Diptera) of Florida. Orlando: Depart. of Environmental Regulation. 308 p.

ESTEVES, FA., 1998. Fundamentos de limnologia. Rio de Janeiro: Interciencia. $602 \mathrm{p}$

GUMIERO, B. and SALMOIRAGHI, G., 1998. Influence of an impoundment on benthic macroinvertebrate habitat utilization. Verh. Internat. Verein. Limnol., vol. 26, p. 2063-2069.

HÅKANSON, L. and JANSSON, N., 1983. Principles of lake sedimentodology. Berlim: Sringer-Verlag. 316 p.

HENRY, R., NUNES, MA., MITSUKA, PM., LIMA, N. and CASANOVA, SMC., 1998. Variação espacial e temporal da produtividade primária pelo fitoplâncton na represa de Jurumirim (Rio Paranapanema, SP). Rev. Brasil. Biol. $=$ Braz. J. Biol., vol. 58, no. 4, p. 571-590.

HIGUTI, J., ZVIEJKOVSKI, LP., TAKAHASHI, MA., and DIAS, VG., 2005. Chironomidae indicadora do estado trófico em reservatórios. In RODRIGUES, L., THOMAZ, SM., AGOSTINHO, AA. and GOMES, LC. (Eds.). Biocenoses em Reservatórios. Padrões espaciais e temporais. São Carlos: Rima. 137-145.

ITUARTE, CF., 1981. Primera noticia acerca de la introducción de pelecípodos asiáticos en el área rioplatense. Neotropica, vol. 27 , no. 77 , p. $79-82$.

KUDO, FA., JORCIN, A., NOGUEIRA, MG., 2006. Composição e Distribuição da Comunidade Zoobentônica em Áreas de Várzea do Rio Paranapanema (SP/PR). In Ecologia de Reservatórios - Impactos Potenciais, Ações de Manejo e Sistemas em Cascata. 2 ed. São Carlos: Rima. p. 379-416.

JORCIN, A. and NOGUEIRA, MG., 2005a. Phosphate distribution in the sediments along a cascade of reservoirs (Paranapanema River, SE, Brazil). In SERRANO, L. and GOLTERMAN, HL. (Eds.). Phosphate in Sediments. Proceeding of the $4^{\text {th }}$ International Symposium. Backhuys, p. 77-86.

-, 2005b. Temporal and Spatial Patterns Based on Sediment and Sediment-Water Interface Characteristics Along a Cascade of Reservoirs (Paranapanema River, south-east Brazil). Lakes Reserv.: Res. Manage., vol. 10, no.1, p. 1-12.

JORCIN, A., NOGUEIRA, MG. and BELMONT, R. Spatial and temporal distribution of the zoobenthos community during the filling up period of Porto Primavera Reservoir (River Paraná, Brazil). Braz. J. Biol. (In press).

LOPRETTO, EC. and TELL, G., 1995. Ecosistemas de aguas continentales. Metodologias para su estudio. Tomos I, II e III. Argentina: Ediciones Sur. 1401 p.

MANSUR, MCD., SCHULZ, C. and GARCES, LM., 1987. Moluscos Bivalves de água doce: identificação dos gêneros do Sul e Leste do Brasil. Acta Biol. Leopoldensia, vol. 9, no. 2, p. 181-202.

MARCHESE, MR., 1995. Annelida Oligochaeta. In LOPRETTO, EC. and TELL, G. (Eds.). Ecosistemas de aguas continentales. Metodologias para su estudio. Tomo II. Argentina: Ediciones Sur. p. 709-727.

MERRIT, RW. and CUMMINS, KW., 1996. An Introduction to the Aquatic Insects of North America. 3 ed. Kendall: Hunt. $862 \mathrm{p}$. 
NOGUEIRA, MG., JORCIN, A., VIANNA, NC. and BRITTO, Y., 2002. Uma avaliação dos processos de eutrofização nos reservatórios em cascata do rio Paranapanema (SP/PR), Brasil. In CIRELLI, AF. and CHALAR, GM. (Eds.). El água en iberoamérica. De la limnológica a la gestión en Sudamérica. Buenos Aires: CYTED XVII - CETA. p. 91-106.

NOGUEIRA, MG., JORCIN, A., VIANNA, NC. and BRITTO, YCT., 2006. Reservatórios em Cascata e os Efeitos na Limnologia e Organização das Comunidades Bióticas (Fitoplâncton, Zooplâncton e Zoobentos) - Um Estudo de Caso no Rio Paranapanema (SP/PR). In NOGUEIRA, MG., HENRY, R. and JORCIN, A. (Eds.). Ecologia de Reservatórios: Impactos Potenciais, Ações de Manejo e Sistemas em Cascata. 2 ed. São Carlos: Rima. p. 83-126

NOGUEIRA, MG. and JORCIN, A., 2006. Contaminação dos sedimentos na bacia hidrográfica do rio Paranapanema (SE, Brasil) por pesticidas sintéticos e metais e sua relação com os processos de eutrofização. In TUNDISI, JG., MATSUMURATUNDISI, T. and GALLI, CS. (Eds.). Eutrofização na América do Sul: causas, consequências e tecnologias para gerenciamento e controle. São Carlos: IIE/DMD propaganda e marketing. p. 103-118.

PENNAK, RW., 1989. Freshwater invertebrates of the United States. Protozoa to Mollusca. 3 ed. New York: John Wiley and Sons, Inc. 628 p.

RESENDE, DLMC., TAKEDA, AM. and KOBAYASHI, JT., 2003. Distribuição espacial de larvas de Chironomidae (Diptera) no reservatório de Rosana, rio Paranapanema, SP/ PR. In RODRIGUES, L., AGOSTINHO, AA., GOMES, LC. and THOMAZ, SM., (Eds.). Produtividade em reservatórios $e$ bioindicadores. Maringá, PR: Universidade Estadual de Maringá. p. 137-143.

SANTOS, CM. and HENRY, R., 2001. Composição, distribuição e abundância de Chironomidae (Díptera, Insecta) na represa de Jurumirim (rio Paranapanema-SP). Acta Limnol. Bras., vol. 13, no. 2, p. 99-115.
TAKEDA, AM., 1999. Oligochaeta community of alluvial upper Paraná River, Brazil: spatial and temporal distribution (1987-1988). Hydrobiologia, vol. 412, p. 35-42.

TAKEDA, AM., SHIMIZU, GY. and HIGUTI, J., 1997. Variações espaço-temporais da comunidade zoobentônica. In VAZZOLER, AEAM., AGOSTINHO, AA. and HAHN, NS. (Eds.). A planície de inundação do alto Rio Paraná. Aspectos físicos, biológicos e socioeconômicos. Maringá: UEM-Nupelia. p. 157-177.

TAKEDA, AM., STEVAUX, JC. and FUJITA, DS., 2001. Effect of hydraulics, bed load grain size and water factors on habitat and abundance of Narapa Bonettoi Righi and Varela, 1983 of the Upper Paraná River, Brazil. Hydrobiologia, vol. 463, p. 241-248.

TAKEDA, AM., MANSU, MCD. and FUJITA, DS., 2005a. Ocorrência de moluscos bivalves em diferentes reservatórios. In RODRIGUES, L., THOMAZ, SM., AGOSTINHO, AA. and GOMES, LC. (Eds.). Biocenoses em Reservatórios. Padrões espaciais e temporais. São Carlos: Rima. p. 161-167.

TAKEDA, AM., BUTAKKA, CMM., FUJITA, DS., FUJITA, RH. and BIBIAN, JPR., 2005b. Larvas de Chironomidae em cascata de reservatórios no Rio Iguaçu (PR). In RODRIGUES, L., THOMAZ, SM., AGOSTINHO, AA. and GOMES, LC. (Eds.). Biocenoses em Reservatórios. Padrões espaciais e temporais. São Carlos: Rima. p. 147-159.

TRIVINHO-STRIXINO, S. and STRIXINO, G., 1995. Larvas de Chironomidae (Diptera) do Estado de São Paulo. Guia de Identificação e diagnose dos gêneros. São Carlos: PPG-ERN/ UFSCAR. 229 p.

WIEDERHOLM, T., 1983. Chironomidae of the Holartic region. Keys and diagnoses. Part 1: Larvae. Ent. Scand., Suppl. 19, p. 1-457.

WRIGHT, JF., FURSE, MT. and ARMITAGE, PD., 1994. Use of macroinvertebrate communities to detect environmental stress in running waters. In SUTCLIFFE, DW. (Ed.). Water quality and stress indicators in marine and freshwater systems: linking levels of organization. Kendal: Freshwater Biological Association. p. 15-34. 